\title{
Root canal length measurement of molar teeth using cone- beam computed tomography (CBCT): comparison of two- dimensional versus three-dimensional methods
}

\section{Purpose}

This study aimed to evaluate the validity of 2-dimensional (2D) and 3-dimensional (3D) cone-beam computed tomographic (CBCT) root canal length measurements of molar teeth compared with actual root canal lengths and the influence of canal curvature on the accuracy of CBCT measurements.

\section{Materials and Methods}

Seventy root canals of 24 molar teeth were scanned using CBCT, and the root canals were categorized as; 'straight/curved,' 'highly curved,' and 'multiple curved.' The 2D measurements were performed within a suitable slice between the major foramen and the corresponding cusp. The 3D measurements were performed within the slices in regular intervals of axial planes in between the same reference points. The reproducibility and reliability of the methods were analyzed by intraclass correlation coefficient. Differences between the actual and CBCT root canal lengths were evaluated by chi-square and McNemar tests if the measurements were within acceptable limits of $\pm 0.5 \mathrm{~mm}$.

\section{Results}

Both methods were found to be reproducible and presented excellent reliability. However, the 3D method was significantly more accurate, with an $85.7 \%$ frequency of measurements within acceptable limits $(p<0.05)$. In 'multiple curved' root canals, the $3 \mathrm{D}$ method presented more reliable measurements than the $2 \mathrm{D}$ method. For 'straight/curved' root canals, the 2D method gave results significantly closer to the actual root canal length in comparison with 'highly curved' root canals $(p<0.05)$.

\section{Conclusion}

The 3D measurements are more accurate than 2D measurements. If an already existing $C B C T$ is present, it could be an alternative method for predetermination of root canal lengths in molar teeth.

Keywords: Cone-beam computed tomography, Root canal, Two-dimensional, Threedimensional, Endodontics

\section{Introduction}

The cone-beam computed tomography (CBCT) is a diagnostic imaging modality that provides a 3-dimensional (3D) visualization of the maxillofacial region. Because $\mathrm{CBCT}$ has the advantage of lower radiation dose compared with computed tomography (CT), it has become a useful method for treatment planning in various dental specialties, including endodontics (1-3). Currently, CBCT has an essential role in endodontic research for detecting apical periodontitis in both pre- or post-endodontic treatment, root fractures, perforations, internal/external root resorption, treatment planning in apical surgery or dental trauma cases, as well as exploration of root canal anatomy (4-11).

\author{
Selen Nihal Sisli ${ }^{1} \mathbb{D}^{\mathbb{D}}$ \\ Orhan Gülen ${ }^{2}$
}

ORCID IDs of the authors: S.N.S. 0000-0002-6718-3425; O.G. 0000-0003-0722-6494

'Department of Endodontics, Faculty of Dentistry, Baskent University, Ankara, Turkey

${ }^{2}$ Dentomaxillofacial Radiology, DentisTomo Private Imaging Center, Ankara, Turkey

Corresponding Author: Selen Nihal Sisli

E-mail: selennihalsarac@gmail.com

Received: 2 November, 2019 Revised: 7 March, 2020 Accepted: 8 January, 2021

DOI: 10.26650/eor.20210124 
CBCT has many advantages over periapical or panoramic radiography such as the absence of image distortion, magnification, and superimposition but the radiation dose is significantly higher (12-14). In endodontics, the application of CBCT should be preferred when the third dimension is needed to perform an accurate diagnosis. However, it should not be used routinely (14). Furthermore, already existing CBCT data should be analyzed to obtain additional information within the FOV for details outside the region of interest. This may decrease the need for additional periapical radiographs $(15,16)$.

CBCT images of the scanned area could be visualized in mesio-distal, bucco-lingual, coronal planes, as well as in three orthogonal planes at the same time. This enables the observer to examine the root canal curvatures and the position of the major foramen location, which is not always possible using periapical radiography (3). Some investigators reported in in-vitro, in situ, and in-vivo studies that the improved visualization of root canal morphology with CBCT could increase the accuracy of root canal length determination (17-25). In most of these studies, single-rooted teeth with straight single root canals were preferred in a vertical position to visualize, whenever possible, the whole length of the canal in a single slice $(17,20,21,23-25)$. Some of these studies concerned the accuracy of root canal length determination with CBCT in multi-rooted or curved root canals $(18,19,22,26,27)$. Few studies compared 3D and 2D measurements $(19,21)$. Therefore, the aims of the present study were; first to compare the validity of $2 \mathrm{D}$ and $3 \mathrm{D}$ CBCT root canal length measurements and second, to evaluate the influence of root canal curvature on the accuracy of both $C B C T$ root canal length measurement methods.

\section{Materials and Methods}

\section{Study sample}

Approval to use extracted human teeth in this study was granted by the Ethics Committee (Project No: D-KA 17/12). A priori power analysis revealed that the minimum sample size should be 70 root canals for $a=0.05$ and to reach the power of $80 \%$. Freshly extracted lower molar teeth were collected. Teeth with cracks, resorption, fractures, immature apexes, previous root canal treatment, amalgam, or crown restorations, extensive coronal caries resulting in loss of cusp structure/ points of reference, signs of hypercementosis, were excluded. Finally, a total of 70 root canals of 24 lower molar teeth were included. The teeth were kept in 10\% formalin solution. After cleaning the calculus and soft tissue remnants, each tooth was numbered on the buccal surface and embedded into rectangular models with a height of 3.5 $\mathrm{cm}$ and a length of $4 \mathrm{~cm}$, made from silicone putty (Zetaplus, Zhermack, Marl, Germany). A total of 6 silicone models with 4 teeth embedded in each were obtained. Also, a thin metal rod was placed on the front surface of each silicone model to determine the buccal surfaces of the teeth.

\section{Imaging protocols}

Preoperatively, teeth were scanned with a CBCT device (Carestream Kodak 9300 C; Rochester, New York, USA) at 80
$\mathrm{kV}$ and $10 \mathrm{~mA}, 8.01 \mathrm{~s}$ exposure time, (100x100 mm FOV) and $180 \mu \mathrm{m}$ voxel size. CS 3D Viewer Software (Carestream Kodak 9300 C; Rochester, New York, USA) was used for the reconstruction of the images and the measurements of the root canal curvatures. If the root canal had one curvature and measured $<25^{\circ}$, it was classified as 'straight/curved,' otherwise it was considered 'highly curved' (18). If the root canal had more than one curvature, it was classified as 'multiple curved' The open source software OsiriX-Lite DICOM Viewer (Pixmeo, SARL, Switzerland) was used for the measurements of the root canal lengths. A single experienced investigator performed all measurements in the CBCT images.

\section{$2 D$ measurements}

The 2D measurements of the root canal lengths on CBCT images were performed as described by Janner et al. (23). For the measurement of each root canal length, the coronal reference point was taken as the corresponding/adjacent cusp (buccal cusp for buccal root canal) and the apical reference point was taken as the major foramen. Firstly, the tooth was rotated by the operator to adjust the coronal and axial planes until the long axis of the root canal, the coronal reference, pulp chamber, major foramen, and, if possible, the whole length of the canal in one single slice made visible. The selection of the most suitable slice, either the sagittal or coronal one, was dependent on the curvature of the root and location of the major foramen. In highly curved and multiple curved root canals, the polyline tracing tool was used, following each visible canal curvature in the respective CBCT slice (24). The measurements obtained were recorded as $2 \mathrm{D} C B C T$ root canal length (Figure 1). Except for the rotation procedures and saturation/contrast adjustments, the images were not manipulated.

\section{D measurements}

The 3D measurements of the root canal lengths on CBCT images were performed as described by Tchorz et al. (19). The major foramen, as the most apical reference point, was detected in the sagittal and axial planes. The center of the root canal in all following axial slices were pointed in regular intervals until the coronal reference point is reached. The coordinates of all points were documented and the 3D CBCT root canal length measurements were obtained by adding the distances between adjacent points (Figure 2). The 3D measurements were performed 2 weeks after the 2D measurements are completed. Reproducibility of all CBCT measurements was determined by repeating the measurement procedures after 1 month.

\section{Actual root canal length measurements}

The specimens were removed from their models, and the endodontic access cavities were prepared. The pulp tissues were removed using barbed broaches. After controlling the patency with the \#8 K-File (Dentsply Maillefer), coronal flaring was performed using SX rotary files (ProTaper, Dentsply Maillefer, Ballaigues, Switzerland) to gain straight-line access. The actual root canal lengths were determined by a different blinded investigator, by inserting the $10 \mathrm{~K}$-file into 
the root canal until the file tip became visible at the apical foramen under $4 \mathrm{x}$ magnification using an operating microscope (Leica Microsystems, Wetzlar, Germany). The rubber stop was placed at the predefined coronal reference point, and the actual root canal length was measured using an electronic digital caliper with a resolution of $0.01 \mathrm{~mm}$ (Allendale Electronics Ltd, New Scotland, Canada). After repeating the measurements, the average of two measurements was recorded as the actual root canal length.

\section{Statistical analysis}

IBM SPSS Statistics 22 (IBM Corp. Released 2013. IBM SPSS Statistics for Windows, Version 22.0. Armonk, NY: IBM Corp, USA) software was used for statistical evaluation. Intraclass correlation coefficients (ICCS) were used to analyze the reproducibility of both $2 \mathrm{D}$ and $3 \mathrm{D} C B C T$ root canal length measurements, and also to assess the reliability of CBCT in measuring root canal length. In addition, chi-squared and McNemar tests were used to evaluate the differences between the actual and CBCT root canal lengths if the CBCT measurements were within acceptable limits of $\pm 0.5 \mathrm{~mm}$. Significance was assessed at $p<0.05$ level.

\section{Results}

According to the root canal curvature classification; 35 (50\%) of the root canals were 'straight/curved,' 24 (34.3\%) were 'highly curved,' and 11 were (15.7\%) 'multiple curved' root canals (Figure 3 ). Since an excellent reliability was observed between the first and second values of the CBCT 3D (ICC =0.992; CI 95\%: 0.988-0.995, p: 0.000) and 2D measurements (ICC $=0.965 ; \mathrm{Cl} 95 \%$ : 0.944-0.978; p: 0.000), the first measurements were used in the other comparisons of the study.

Mean variation between measurements of actual root canal lengths and 2D CBCT root canal lengths was $0.5 \mathrm{~mm}$ (ICC $=0.943 ; \mathrm{Cl} 95 \%$ : 0.910-0.964; $\mathrm{p}: 0.000)$ and for 3D CBCT root canal lengths it was $0.28 \mathrm{~mm}$ (ICC $=0.979$; $\mathrm{Cl} 95 \%$ : $0.968-$ 0.986; p: 0.000). In 60 root canals (85.7\%), measurements of 3D CBCT root canal length were within acceptable limits $( \pm 0.5 \mathrm{~mm})$; in 10 root canals $(14.3 \%), 3 \mathrm{D}$ CBCT measurements were short. In 46 root canals (65.7\%), measurements of $2 \mathrm{D}$ CBCT root canal length were within acceptable limits; in 5 root canals (7.1\%), 2D CBCT measurements were long, while in 19 root canals (\%27.1) 2D CBCT measurements were short. According to these findings, measurements of $3 \mathrm{D} C B C T$ root canal length were significantly more accurate than the measurements of 2D CBCT ( $\mathrm{p}: 0.005 ; \mathrm{p}<0.05 ; \mathrm{Mc} \mathrm{Ne}-$ mar Test).

In 'straight/curved' and 'highly curved' root canals, both $2 \mathrm{D}$ and $3 \mathrm{D}$ CBCT root canal length measurements presented strong, positive, and significant correlations with actual root canal lengths ( $p: 0.000, p<0.05$ ). In 'multiple curved' root canals, 3D CBCT root canal length measurements presented excellent reliability $(\mathrm{ICC}=0.930 ; \mathrm{Cl} 95 \%$ : 0.867-0.964; p: 0.000 ) with actual root canal lengths, whereas $2 \mathrm{D} C B C T$ root canal length measurements presented substantial reliability (ICC=0.698; Cl 95\%: 0.204-0.909; p: 0.006). Between the subgroups of curvature classification, in comparisons according to acceptable limits, 2D CBCT measurements showed a sig- nificant difference (Table 1), unlike 3D CBCT measurements (Table 2). In two-paired comparisons, the differences between 'straight/curved' and 'highly curved' root canals were found to be significant ( $p: 0.006 ; p<0.05)$.

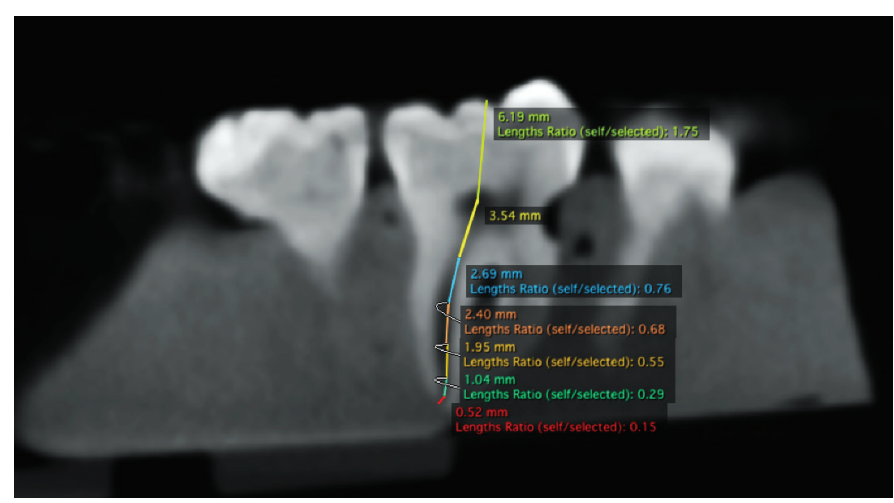

Figure 1. Representative illustration of a two-dimensional cone-beam computed tomographic measurements of root canal length.

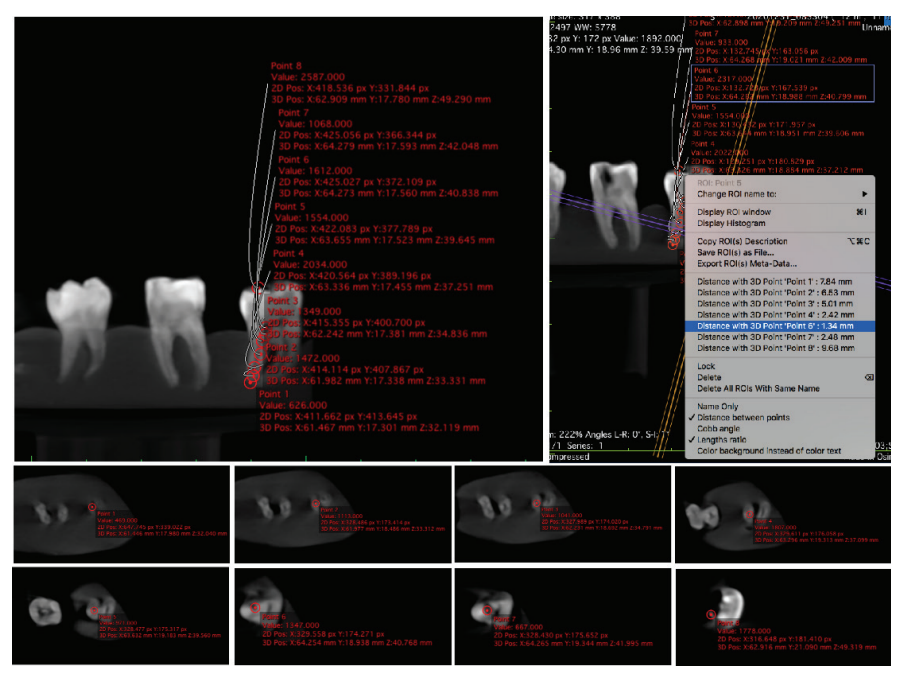

Figure 2. Representative illustration of a three-dimensional cone-beam computed tomographic measurements of root canal length.
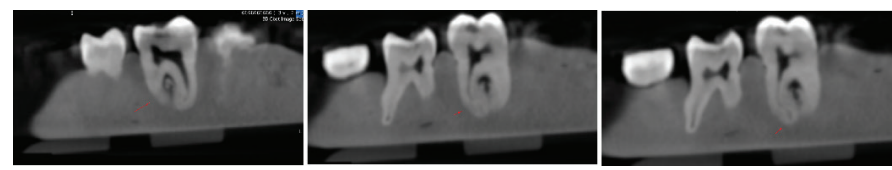

Figure 3. Sagittal slices of a root canal with multiple curves.

Table 1. Evaluation of the accuracy $( \pm 0.5 \mathrm{~mm})$ between the

measurements of actual and 2D CBCT root canal lengths according to curvature classification Chi-Square test $\left.{ }^{*} p<0.05\right)$.

\section{CBCT 2D}

\begin{tabular}{lcccc}
\hline & $\begin{array}{c}\text { Within } \\
\text { acceptable } \\
\text { limits }(\mathbf{\pm 0 . 5} \\
\mathbf{m m})\end{array}$ & $\begin{array}{c}\text { Longer than } \\
\text { actual root } \\
\text { canal lengths } \\
(>\mathbf{0 . 5} \mathbf{~ m m})\end{array}$ & $\begin{array}{c}\text { Shorter than } \\
\text { actual root } \\
\text { canal lengths } \\
(<\mathbf{0 . 5} \mathbf{~ m m})\end{array}$ & p \\
\hline & $\mathbf{n}(\%)$ & $\mathbf{n}(\%)$ & $\mathbf{n}(\%)$ & \\
\hline $\begin{array}{l}\text { Straight } \\
\text { Curved }\end{array}$ & $27(77.1 \%)$ & $4(11.4 \%)$ & $4(11.4 \%)$ & $0.039^{*}$ \\
\hline $\begin{array}{l}\text { Highly } \\
\text { Curved }\end{array}$ & $13(54.2 \%)$ & $0(0 \%)$ & $11(45.7 \%)$ & \\
\hline $\begin{array}{l}\text { Multiple } \\
\text { Curved }\end{array}$ & $6(54.5 \%)$ & $1(9.1 \%)$ & $4(36.4 \%)$ & \\
\hline
\end{tabular}


Table 2. Evaluation of the accuracy $( \pm 0.5 \mathrm{~mm})$ between the

measurements of actual and 3D CBCT root canal lengths according to curvature classification (Chi-Square test).

\section{CBCT 3D}

\begin{tabular}{|c|c|c|c|c|}
\hline & $\begin{array}{c}\text { Within } \\
\text { acceptable } \\
\text { limits }( \pm 0.5 \\
\mathrm{mm})\end{array}$ & $\begin{array}{l}\text { Longer than } \\
\text { actual root } \\
\text { canal lengths } \\
(>0.5 \mathrm{~mm})\end{array}$ & $\begin{array}{l}\text { Shorter than } \\
\text { actual root } \\
\text { canal lengths } \\
(<0.5 \mathrm{~mm})\end{array}$ & $\mathbf{p}$ \\
\hline & n (\%) & n (\%) & n (\%) & \\
\hline $\begin{array}{l}\text { Straight/ } \\
\text { Curved }\end{array}$ & 30 (85.7\%) & $0(0 \%)$ & $5(14.3 \%)$ & 0.237 \\
\hline $\begin{array}{l}\text { Highly } \\
\text { Curved }\end{array}$ & 21 (87.5\%) & $0(0 \%)$ & $3(14.2 \%)$ & \\
\hline $\begin{array}{l}\text { Multiple } \\
\text { Curved }\end{array}$ & $9(81.8 \%)$ & $0(0 \%)$ & $2(18.2 \%)$ & \\
\hline
\end{tabular}

\section{Discussion}

Our results suggest that $2 \mathrm{D}$ and $3 \mathrm{D}$ CBCT measurements are both reproducible and successful methods for predetermination of root canal length in molar teeth. However, the 3D method displayed significantly more accurate root canal length determination, and excellent reliability compared to the 2D method. In 'multiple curved' root canals, the 3D method presented more reliable measurements than the 2D method. The 2D method showed a tendency for underestimation of the 'highly curved' root canals compared to 'straight/curved' root canals (Table 1).

In most of the previous studies on the predetermination of root canal length using $\mathrm{CBCT}$, teeth with straight and single root canals have been used, and $2 \mathrm{D}$ measurements have been performed in 3D environment $(17,20,23-25)$. Only one study compared 2D and 3D CBCT approaches for predetermination of root canal length in molar teeth (19). According to the findings of that one, which are in agreement with ours, differences between actual root canal lengths and 3D measurements were significantly less than those seen with 2D measurements. Mean discrepancies were 0.32 and 0.58 $\mathrm{mm}$, respectively. A high correlation was found between the actual root canal length and 3D measurements, and $80 \%$ of the 3D measurements were within acceptable limits.

In previous in-vitro studies using the 2D approach, Lucena et al. (18), Connert et al. (22), and Metska et al. (26) (in-situ) reported the mean discrepancies of $0.59 \mathrm{~mm}, 0.41 \mathrm{~mm}$, and $0.74 \mathrm{~mm}$ for anterior, $0.51 \mathrm{~mm}$ for posterior teeth between the measurements of $C B C T$ and actual root canal lengths, respectively. On the other hand, in a very recent in-vitro study, Yilmaz et al. (20) have found that measurement of root canal length with $C B C T$ at different voxel sizes resulted in underestimation of between 1.16 and $1.63 \mathrm{~mm}$. In addition, in clinical studies that used the 2D approach, Janner et al. (23) and Jeger et al. (24) reported a mean discrepancy of $0.4 \mathrm{~mm}$ and $0.51 \mathrm{~mm}$ between the measurements of CBCT and electronic apex locator, respectively. Similarly, Ustun et al. (25) found no significant difference between CBCT measurements and electronic apex locator (25). These researchers commonly concluded that existing CBCT images might be useful for endodontic working length determination.
Since CBCT became popular in endodontics as the imaging modality for treatment planning in complex cases, most patients who apply for root canal treatment might already have an existing CBCT (14). The incidental appearance of the endodontic treatment planned tooth in the field of view (FOV) would provide valuable information about the complexities such as curvatures, confluences and predetermination of the root canal length $(15,16,20,22)$. While most of the CBCT software currently in use can measure $2 \mathrm{D}$ root canal length with the linear measurement tool, it is impossible to measure 3D root canal length with the same practicality. Drawing a point-route by following the canal trajectory from axial sections and measuring each pointss distance will be very difficult and time-consuming when considering the clinical reality. Besides, measurements with non-automated programs can be affected by the skills and experience of the operator. Based on this fact, a new CBCT software that presents automated functions for preoperative root canal length measurement has been developed and the predetermination of the root canal lengths was found to be reliable (21, $27,28)$.

Based on the results obtained from both previous studies and the present study, an already existing CBCT image can be useful in predetermining the working length in endodontic clinics and may result in the need for fewer periapical radiographs, which will support the as low as reasonably achievable' (ALARA) principle of radiology $(15,17-28)$.

\section{Conclusion}

3D measurements of root canal length in molar teeth are more accurate than 2D measurements and already available CBCT scans could be an alternative method for predetermination of root canal length in molar teeth. Further clinical studies using the 3D method will also contribute to clarifying this issue.

Türkçe Özet: Konik-ışınlı bilgisayarlı tomografi (kıbt) kullanılarak molar dişlerde kök kanal uzunluğu ölçümü: iki boyutlu ve üç boyutlu yöntemlerin karşılaştırılması. Amaç: Bu çalışmada amaç, büyük azı dişlerinin 2 boyutlu (2D) ve 3 boyutlu (3D) konik-ışınlı bilgisayarlı tomografik (KIBT) yöntemleri ile gerçekleştirilen kök kanal uzunluğu ölçümlerinin, gerçek kök kanal uzunluklarılla uyumunun incelenmesidir. Gereç ve yöntem: 24 büyük azı dişe ait 70 kök kanalı KIBT ile tarandı ve kök kanalları eğimlerine göre "Düz", "Aşırı kurvatürlü" ve "Birden fazla kurvatüre sahip" olarak sınıflandırılmıştır. 2D ölçümler, uygun bir KIBT kesitinde, kök kanalının foramen apikalesi ile ilgili kanalın tüberkül tepesi referans alınarakyapılmıştır. 3D ölçümler, aynı referans noktaları arasında düzenli aralıklarla ilerleyen aksiyal kesitler içerisinde gerçekleştirilmiştir. KIBT ile ölçüm yöntemlerinin tekrarlanabilirlik ve güvenilirlik analizinde Sınıf İçi Korelasyon Katsayısı kullanılmıştır. Gerçek kök kanal uzunluğu ve KIBT ile kök kanal uzunluğu ölçümleri arasındaki farkların kabul edilebilir sınırlar dahilinde $( \pm 0,5 \mathrm{~mm})$ olup olmadığı ki-kare ve McNemar testleri ile değerlendirilmiştir. Bulgular: Her iki yöntemin de tekrarlanabilir olduğu ve mükemmel güvenilirlik sağladığı gözlemlendi. Bununla birlikte, 3D yöntemi ile elde edilen ölçümler $\% 85,7$ oranla kabul edilebilir sınırlar dahilinde bulunmuştur ve 2D yöntemi ile arasındaki fark istatistiksel olarak anlamlı bulunmuştur $(p<0.05)$. "Birden fazla kurvatüre sahip" kök kanallarında, 3D yöntemi ile yapılan kök kanal uzunluğu ölçümleri 2D metodundan daha güvenilir bulunmuştur. "Düz" kök kanalları için 2D yöntemi "Aşırı kurvatürlü"'kök kanallarına kıyasla gerçek kök kanal uzunluğuna önemli ölçüde yakın sonuçlar vermiştir $(p<0.05)$. Sonuç: 3D yöntemi ile 2D yöntemine kıyasla daha doğru kök kanal uzunluğu ölçümleri elde edilebilinir. Hali hazırda mevcut bir KIBT görüntüsü varsa, büyük azı dişlerinde kök kanal uzunluklarının tedaviye başlamadan önce belirlenmesinde alternatif olarak kullanılabilinir. 
Anahtar Kelimeler: Konik-ışınlı bilgisayarlı tomografi, Kök kanalı, Iki boyutlu, Üç boyutlu, Endodonti

Ethics Committee Approval: This study was approved by Baskent University Institutional Review Board (Project No: D-KA 17/12).

Informed Consent: Participants provided informed consent.

Peer-review: Externally peer-reviewed.

Author contributions: SNS and OG participated in generating the data for the study. SNS and OG participated in gathering the data for the study. SNS and OG participated in the analysis of the data. SNS wrote the majority of the original draft of the paper. SNS and OG participated in writing the paper. SNS has had access to all of the raw data of the study. SNS has reviewed the pertinent raw data on which the results and conclusions of this study are based. SNS and OG have approved the final version of this paper. SNS guarantees that all individuals who meet the Journal's authorship criteria are included as authors of this paper. SNS and OG participated in designing the study.

Conflict of Interest: Authors had no conflict of interest to declare.

Financial Disclosure: This study was supported by the Baskent University Research Fund.

\section{References}

1. De Vos W, Casselman J, Swennen GR. Cone-beam computerized tomography $(\mathrm{CBCT})$ imaging of the oral and maxillofacial region: a systematic review of the literature. Int J Oral Maxillofac Surg 2009;38:609-25. [CrossRef]

2. Lofthag-Hansen S, Huumonen S, Gröndahl K, Gröndahl HG. Limited cone-beam CT and intraoral radiography for the diagnosis of periapical pathology. Oral Surg OralMed Oral Pathol Oral Radiol Endod 2007;103:114-9. [CrossRef]

3. Patel S, Dawood A, Pitt Ford T, Whaites E. New dimensions in endodontic imaging: part 2. Cone beam computed tomography. Int Endod J 2009;42:463-75. [CrossRef]

4. de Paula-Silva FW, Wu MK, Leonardo MR, da Silva LA, Wesselink PR. Accuracy of periapical radiography and cone-beam computed tomography scans in diagnosing apical periodontitis using histopathological findings as a gold standard. J Endod. 2009;35:1009-12. [CrossRef]

5. Metska ME, Aartman IH, Wesselink PR, Özok AR. Detection of vertical root fractures in vivo in endodontically treated teeth by cone-beam computed tomography scans. J Endod 2012;38:1344-7. [CrossRef]

6. Shemesh H, Cristescu R, Wesselink PR, Wu MK. The use of conebeam computed tomography and digital periapical radiographs to diagnose root perforations. J Endod 2011;37:513-6.[CrossRef]

7. Kamburoglu K, Kursun S, Yuksel S, Oztas B. Observer ability to detect ex vivo simulated internal or external cervical root resorption. J Endod 2011;37:168-75. [CrossRef]

8. Ziegler CM, Woertche R, Brief J, Hassfeld S. Clinical indications for digital volume tomography in oral and maxillofacial surgery. Dentomaxillofac Radiol 2002;31:126-30. [CrossRef]

9. Bornstein $M M$, Wölner-Hanssen $A B$, Sendi $P$, von Arx $T$. Comparison of intraoral radiography and limited cone beam computed tomography for the assessment of root-fractured permanent teeth. Dent Traumatol 2009;25:571-7. [CrossRef]

10. Demirbuga S, Sekerci AE, Dincer AN, Cayabatmaz M, Zorba YO. Use of cone-beam computed tomography to evaluate root and canal morphology of mandibular first and second molars in Turkish individuals. Med Oral Patol Oral Cir Bucal 2013;18:737-44. [CrossRef]

11. Michetti J, Maret D, Mallet JP, Diemer F. Validation of cone beam computed tomography as a tool to explore root canal anatomy. J Endod 2010;36:1187-90. [CrossRef]
12. Patel S, Durack C, Abella F, Shemesh H, Roig M, Lemberg K. Cone beam computed tomography in endodontics-a review. Int Endod J 2015;48:3-15. [CrossRef]

13. Estrela C, Bueno MR, Leles CR, Azevedo B, Azevedo JR. Accuracy of cone beam computed tomography and panoramic and periapical radiography for detection of apical periodontitis. J Endod 2008;34:273-9. [CrossRef]

14. American Association of Endodontists, American Academy of Oral and Maxillofacial Radiology. AAE and AAOMR joint position statement use of cone beam computed tomography in endodontics 2015 update. J Endod 2015;41:1393-6. [CrossRef]

15. Caglayan F, Tozoglu U. Incidental findings in the maxillofacial region detected by cone beam CT. Diagn Interv Radiol 2012;18:159-63. [CrossRef]

16. Oser DG, Henson BR, Shiang EY, Finkelman MD, Amato RB. Incidental Findings in Small Field of View Cone-beam Computed Tomography Scans. J Endod 2017;43:901-4. [CrossRef]

17. Sherrard JF, Rossouw PE, Benson BW, Carillo R, Buschang PH. Accuracy and reliability of tooth and root lengths measured on cone-beam computed tomographs. Am J Orthod Dentofacial Orthop 2010;137:100-8. [CrossRef]

18. Connert T, Hulber JM, Godt A, Löst C, ElAyouti A. Accuracy of endodontic working length determination using cone beam computed tomography. Int Endod J 2014;47:698-703. [CrossRef]

19. Tchorz JP, Poxleitner PJ, Stampf S, Patzelt SBM, Rottke D, Hellwig $E$, et al. The use of cone beam computed tomography to predetermine root canal lengths in molar teeth: a comparison between two-dimensional and three-dimensional measurements. Clin Oral Investig 2014;18:1129-33. [CrossRef]

20. Yilmaz F, Kamburoglu K, Senel B. Endodontic Working Length Measurement Using Cone-beam Computed Tomographic Images Obtained at Different Voxel Sizes and Field of Views, Periapical Radiography, and Apex Locator: A Comparative Ex Vivo Study. J Endod 2017;43:152-6. [CrossRef]

21. Segato AVK, Piasecki L, Felipe Iparraguirre Nuñovero $M, d a$ Silva Neto UX, Westphalen VPD, Gambarini G, Carneiro E. The Accuracy of a New Cone-beam Computed Tomographic Software in the Preoperative Working Length Determination Ex Vivo. J Endod 2018;44:1024-9. [CrossRef]

22. Metska ME, Liem VM, Parsa A, Koolstra JH, Wesselink PR, Ozok AR. Cone-beam Computed Tomographic Scans in Comparison with Periapical Radiographs for Root Canal Length Measurement: An In Situ Study. J Endod 2014;40:1206-9. [CrossRef]

23. Janner SF, Jeger FB, Lussi A, Bornstein MM. Precision of endodontic working length measurements: a pilot investigation comparing cone-beam computed tomography scanning with standard measurement techniques. J Endod 2011;37:1046-51. [CrossRef]

24. Jeger FB, Janner SF, Bornstein MM, Lussi A. Endodontic working length measurement with preexisting cone-beam computed tomography scanning: a prospective, controlled clinical study. J Endod 2012;38:884-8. [CrossRef]

25. Ustun Y, Aslan T, Sekerci AE, Sagsen B. Evaluation of the Reliability of Cone-beam Computed Tomography Scanning and Electronic Apex Locator Measurements in Working Length Determination of Teeth with Large Periapical Lesions. J Endod 2016;42:1334-7. [CrossRef]

26. Lucena C, Lopez JM, Martin JA, Robles V, Gonzalez-Rodriguez MP. Accuracy of working length measurement: electronic apex locator versus cone-beam computed tomography. Int Endod J 2014;47:246-56. [CrossRef]

27. Tchorz JP, Wolgin M, Karygianni L, Vach K, Altenburger MJ. Accuracy of CBCT-based root canal length predetermination using new endodontic planning software compared to measurements performed with an electronic apex locator ex vivo. Int J Comput Dent 2018;21:323-8.

28. Tchorz JP, Wrbas KT, Von See C, Vach K, Patzelt SBM. Accuracy of Software Based Three-Dimensional Root Canal Length Measurements Using Cone-Beam Computed Tomography. Eur Endod J 2019;4:28-32. [CrossRef] 